\title{
How do season, on-farm fasting interval and lairage period affect swine welfare, carcass and meat quality traits?
}

\author{
Filipe Antonio Dalla Costa ${ }^{1}$ (D) - Osmar Antonio Dalla Costa ${ }^{2} \cdot$ Arlei Coldebella $^{2}$. \\ Gustavo Júlio Mello Monteiro de Lima ${ }^{2}$. Antonio Sérgio Ferraudo ${ }^{1}$
}

Received: 11 December 2017 / Revised: 28 February 2018 / Accepted: 6 March 2018

(C) ISB 2018

\begin{abstract}
This study was carried out in order to determine the effects of different combinations of on-farm fasting intervals $(8,12,16,20 \mathrm{~h})$ and $1.5 \mathrm{~h}$ of transport plus lairage periods $(1,3,6 \mathrm{~h}$ ) at different seasons (summer/winter) on blood stress parameters (cortisol and lactate), stomach content and weight, skin lesion and meat quality in a total of 960 pigs from eight farms. Blood lactate levels were greater in the summer $(P<0.001)$ and stomach content was affected $(P<0.05)$ by season, on-farm fasting interval $(P<0.001)$, lairage time $(P<0.0001)$. Stomach content weight reduces as the total feed withdrawal time increases up to onfarm fasting of 17 and $1 \mathrm{~h}$ of lairage. Stomach content can be influenced by feed and water in different ways according to treatments. Only $8 \mathrm{~h}$ of on-farm fasting is not enough to empty stomachs from feed content. However, an on-farm fasting period of $16 \mathrm{~h}$ or longer can also increase the occurrence of more water in the stomachs. Carcass lesions caused by fighting were greater $(P \leq 0.005)$ in the winter, mainly after 3 and $6 \mathrm{~h}$ of lairage $(P \leq 0.005)$. Loin and ham $\mathrm{pH}_{\mathrm{u}}$ was lower $(P \leq 0.05)$ for pigs slaughtered after $6 \mathrm{~h}$ of lairage during the summer. The application of $12 \mathrm{~h}$ of on-farm fasting with $6 \mathrm{~h}$ of lairage seemed to be best combination to reduce stomach content weight (feed and water). In the winter, shorter lairage period can be used to reduce percentage of skin lesions and better pork quality traits in pigs.
\end{abstract}

Keywords Cortisol $\cdot$ Feed withdrawal $\cdot$ Lactate $\cdot$ Skin lesion

\section{Introduction}

There are several benefits from feed withdrawal and lairage time before slaughter, such as feed saving on-farm, prevention of animal losses and kinetosis during transport (Averós et al. 2008; Bradshaw et al. 1996; National Farm Animal Care Council 2014), and reduction of carcass contamination due to lower risk of gut content spillage during carcass evisceration (Saucier et al. 2007), recovery from previous stress before arrival at abattoir and improvements in pork quality (Faucitano et al. 2010).

Osmar Antonio Dalla Costa

osmar.dallacosta@embrapa.br

1 Programa de Pós-Graduação em Zootecnia, Faculdade de Ciências Agrárias e Veterinárias, Universidade Estadual Paulista

UNESP-FCAV, Jaboticabal, SP, Brazil

2 Embrapa Suínos e Aves, BR 153, Km 110, Concórdia, SC 89715-899, Brazil
Recommendations for feed withdrawal interval from farm to abattoir vary between 8 and 24 h (Eikelenboom et al. 1991; Faucitano et al. 2010; Dalla Costa et al. 2016a). However, long feed withdrawal can negatively affect the animal welfare, carcass (Brown et al. 1999; Dalla Costa et al. 2016a) and pork quality (Guàrdia et al. 2009; Dalla Costa et al. 2016a) due to greater activity during the lairage period (Dalla Costa et al. 2016a). Indeed, the influence of fasting on glycogen levels in muscle is more pronounced when it is combined with other pre-slaughter handling practices (Leheska et al. 2002).

The lairage period provides a reservoir of animals for the slaughter line, levelling out variations in the delivery schedule to the plant, and it also allows pigs to recover from any previous stress and dehydration that occurred during transport from the farm to the abattoir. A lairage period of 1-3 h has been recommended for its benefits to the welfare of pigs (Warriss 2003), without imposing important harmful effects such as long feed withdrawal, carcass damage or poorer meat quality (Warriss 2003; Young et al., 2009; Dalla Costa et al. 2016a). Longer lairage 
periods may increase the risk of fighting in mixed groups of pigs resulting in a higher incidence of animals with skin and carcass damage and pork quality defects (Faucitano et al. 2010; Guàrdia et al. 2005, 2009; Dalla Costa et al. 2016a). In cases of low stress during loading, transport and unloading, some authors recommend slaughtering pigs on the arrival at the abattoir (Aaslying and Barton Gade 2001). Thus, based on the potential advantages of applying different combinations of on-farm fasting interval and lairage period, further research is needed to understand these effects under commercial conditions (Panella-Riera et al. 2012).

Most studies were conducted in the same period of the year. However, the effects of feed withdrawal during different seasons on animal welfare, stomach content and carcass and pork quality may vary depending on environmental conditions. It is known that thermal stress has an impact on pork quality (Gispert et al. 2000; O'Neill et al. 2003; Guàrdia et al. 2004, 2005). However, the effects of the interaction between the combination of on-farm fasting intervals with lairage periods at different climates on animal welfare, stomach content and carcass and pork quality have not yet been assessed.

Brazil is the fourth largest producer and exporter of pork meat (ABIPECS 2016). For this reason, although there have been no restrictions motivated by animal welfare in international trade regulations, Brazilian pork producers and processors are aware of the pressure that may be imposed by countries importing Brazilian meat to meet their animal welfare standards (Pinheiro Machado Filho 2000; Dalla Costa et al. 2007). Based on the limited ability of heat loss of pig (Ingrain 1965; Adejumo and Egbunike, 1988), climate effects can make difficult to meet these goals in intensive animal production. In Brazil, little research on the effects of on-farm fasting and lairage periods on animal welfare and pork quality has been done. Therefore, information on this matter is needed given the increased production and slaughter volume of pigs which could lead to a higher rate of pig losses to slaughter in Brazil (Dalla Costa et al. 2007).

The objective of this study was to evaluate the effects and interactions of different combinations of on-farm fasting intervals and lairage period at different climates on blood stress parameters, stomach weight and content and carcass and meat quality in pigs.

\section{Materials and methods}

The animal handling procedures used in this research were approved by the São Paulo State University's Animal Research Ethics Board (protocol number 6119-08).

\section{Treatments}

The study consisted of a factorial design $4 \times 3$ (Table 1 ) where four different on-farm feed withdrawal periods $(8,12,16$, $20 \mathrm{~h}$ ) and $1.5 \mathrm{~h}$ of transport were combined with three different lairage periods $(1,3,6 \mathrm{~h})$. All pigs from each pen were removed at the same time, so there were no remaining pigs in the pen. All pigs had unlimited access to water throughout the experiment.

\section{Description of study site}

Eight commercial farms located $88.1 \mathrm{~km}( \pm 28.4 \mathrm{~km})$ from the abattoir, in average, were selected for the study. The same farms were used during the winter (June to August, 2008) and summer (April to May, 2009). During the period of this study, environment data (temperature and relative humidity) was collected from a nearby INMET (Instituto Nacional de Meteorologia) and EMBRAPA Swine and Poultry Stations. The average ambient temperature and relative humidity were $14{ }^{\circ} \mathrm{C}$ (range from 1.5 to $22{ }^{\circ} \mathrm{C}$ ) and $79 \%$ (range from 66 to $91 \%$ ) in the winter and $22{ }^{\circ} \mathrm{C}$ (range from 13 to $32{ }^{\circ} \mathrm{C}$ ) and $75 \%$ (range from 62 to $88 \%$ ) in the summer, respectively. There was no rain during the period of this study.

All farms were similarly designed and consisted of only one growing-finishing facility with capacity to house nearly 650 pigs $( \pm 25)$ per cycle (160 days). A total of 12 pens from each farm received one treatment each following the randomized selection. Pens had concrete floor only and housed $15( \pm 1)$ pigs/pen at density of $1.10 \mathrm{~m}^{2} / \mathrm{pig}$. The topography of roads was usually flat with some steep slopes from farms to abattoir. Pig slaughtering and carcass processing were performed at the same commercial abattoir.

Table 1 Description of experimental treatments

\begin{tabular}{ccll}
\hline $\begin{array}{l}\text { Number of } \\
\text { treatments }\end{array}$ & $\begin{array}{l}\text { On-farm fasting } \\
(\mathrm{h})\end{array}$ & $\begin{array}{l}\text { Lairage period } \\
(\mathrm{h})\end{array}$ & $\begin{array}{l}\text { Fasting period } \\
(\mathrm{h})\end{array}$ \\
\hline 1 & 8 & 1 & 10.5 \\
2 & 12 & 1 & 14.5 \\
3 & 16 & 1 & 18.5 \\
4 & 20 & 1 & 22.5 \\
5 & 8 & 3 & 12.5 \\
6 & 12 & 3 & 16.5 \\
7 & 16 & 3 & 20.5 \\
8 & 20 & 3 & 24.5 \\
9 & 8 & 6 & 15.5 \\
10 & 12 & 6 & 19.5 \\
11 & 16 & 6 & 25.5 \\
12 & 20 & 6 & 27.5 \\
\hline
\end{tabular}

${ }^{1}$ Time of transport was $1.5 \mathrm{~h}$ 
Animals and pre-slaughter management on the farm

Pigs were fed four times per day with a commercial diet (mash feed) using a head-to-head shelf feeder, one per pen. A total of 960 crossbred pigs (BW of $115 \pm 2 \mathrm{Kg}$ ) were randomly selected from eight farms, tagged, weighed and distributed into 12 groups of 10 pigs each. One day before shipping to abattoir, pens were randomly assigned to each treatment of on-farm feed withdrawal (Table 1). On the day of slaughter, each treatment group was loaded into trucks (Triel-HT, Erechim, Brazil; as previously described by Dalla Costa et al. 2016b) at a density of $230 \mathrm{~kg} / \mathrm{m}^{2}$ by a trained crew with the help to handling tools (paddles and rattles) from 23.00 to $02.00 \mathrm{~h}$. Each farm had a loading ramp (11.6 $\pm 0.5-\mathrm{m}$ long), which could be adjustable to reach the bottom and the fixed upper deck ( $15^{\circ}$ and $21^{\circ}$ slope, respectively) of the truck. Thus, pigs were shipped to the abattoir in groups of 60 pigs per replicate (farm) during two seasons ( 60 pigs $\times 2$ seasons $\times 8$ replicates). The journey comprised a total of $88.1 \mathrm{~km}$ ( \pm 28.1$)$, being $9.48 \mathrm{~km}( \pm 6.71)$ on unpaved road and $79.5 \mathrm{~km}( \pm 28.4)$ on paved road, at a mean speed of $36 \mathrm{~km} / \mathrm{h}( \pm 4.92)$, which took $150 \mathrm{~min}( \pm 45)$. During this research, the same driver for each truck was used and the loading order of treatments on each farm was rotated between trucks to avoid effects of driver on the results, as previously done in other studies (Schwartzkopf-Genswein et al. 2012; Dalla Costa et al. 2016a, b, 2017).

\section{Pre-slaughter of pigs abattoir}

Immediately on arrival at the abattoir, animals were unloaded using a metallic ramp $\left(5-\mathrm{m}\right.$ length, slope $\left.\leq 15^{\circ}\right)$ with anti-skid floor using paddles. This ramp could be adjustable for unloading the bottom and upper deck of the truck. At lairage, according to each treatment $(1,3$, $6 \mathrm{~h}$ of lairage; Table 1), pigs were kept in separate pens (no social mixing; 8 pigs/pen; density of $0.6 \mathrm{~m}^{2} / 100 \mathrm{~kg}$ ). Lairage pens had only concrete floor and walls, solid metallic gate and were equipped with bite ball drinkers (one to fifteen pigs with a flow of $1.4 \mathrm{~L} / \mathrm{min}$ ). The temperature at lairage pens was regulated by both a sprinkling system and natural ventilation (vary from 15 to $19{ }^{\circ} \mathrm{C}$ ). Independently of the season, sprinkling system was turned on when ambient temperature was higher than $10{ }^{\circ} \mathrm{C}$ and relative humidity lower than $80 \%$. When each treatment was concluded at lairage, the loading crew conducted the pigs to slaughter using handling tools (paddles, boards and rattles). The slaughter of pigs consisted in head-only electrical stunning (700 V, 1.3 A, 5 s; Valhalla, Stork RMS b.v., Lichtenvoorde, Holland) before exsanguination in the horizontal position (maximum interval of $20 \mathrm{~s}$ ). During data collection, slaughtering speed was $280 \mathrm{pigs} / \mathrm{h}$.

\section{Physiological stress indicators}

A total of 5 pigs $/ 12$ treatments $/ 2$ seasons $/ 8$ repetitions were used for the analysis of cortisol and lactate in the sticking wound blood. The processing and measurements were performed as described by Dalla Costa et al. (2016b, 2017). Briefly, for serum cortisol analysis, blood samples of $10 \mathrm{~mL}$ were collected in tubes (Vacuplast, Cral Artigos para Laboratório Ltd., São Paulo, Brazil) and, for plasma lactate concentration analysis, another tube with $3.0 \mathrm{mg}$ of sodium fluoride and $6.0 \mathrm{mg}$ of $\mathrm{Na}_{2}$ EDTA solution was used. Analysis of plasma lactate was analysed in duplicated. The intra-assay CV was 26.08 and $22.43 \%$ for lactate and cortisol concentration, respectively.

\section{Carcass handling, skin lesion assessment and stomach weight and content}

After processing and evisceration procedures, carcass lesions were visually inspected on each left side of the carcass as fighting-type, handling or mounting-type lesions by the shape and size (ITP 1996; Faucitano 2010) in the chiller. Briefly, fighting lesions were comma shaped (5 to $10 \mathrm{~cm}$ in length) and concentrated in the head and shoulders or in the thigh; mounting lesions were comma shaped (10 to $15 \mathrm{~cm}$ in length and $0.5-$ to $1-\mathrm{cm}$ in wide) caused by the fore claws and densely located on the loin of pigs and handling lesions were large dark brown rectangular marks usually found on any regions of the carcass.

Stomachs were collected directly on the dressing line during evisceration process. They were identified by a tag and stored at $4{ }^{\circ} \mathrm{C}$ until the moment of weighing. All stomachs were weighed full and then emptied of their content. The weights of stomach content are expressed on a wet weight basis. Indeed, the stomach content was collected and subjectively scored. According to a visual score, the following categories were established: full of only water and mucus (no feed content), mix of water and feed usually in a proportion of $50 \%$ approximately and full of only feed.

\section{Meat quality}

The Longissimus dorsi (back) and Semimembranosus (thigh) muscles were used for assessment of meat quality by the $\mathrm{pH}$ at $45 \mathrm{~min}\left(\mathrm{pH}_{\mathrm{i}}\right)$ and $24 \mathrm{~h}\left(\mathrm{pH}_{\mathrm{u}}\right)$ postmortem (pHmeter, HI 8314 model, Hanna Instruments, São Paulo, Brazil), and objective colour (CR-400; Minolta Camera Ltd., Osaka, Japan) and drip loss (EZ-driploss method described by Correa et al. 2007) measurements at $24 \mathrm{~h}$ of slaughter as described by Dalla Costa et al. (2016b, 2017). 


\section{Statistical analysis}

The percentage pigs in each stomach content classification was standardized and submitted to a multivariate analysis using Principal Components Analysis Statistica 7 in order to better understand the behaviour of these variables in each cluster. The following variables: feed; feed + water and water were used to separate the principal components in two dimensions. Data were analysed as factorial design $(4 \times 3$; on-farm fasting interval $\times$ lairage period) to check effects of treatments. Frequencies of lesions and stomach content data were log-transformed to attend the assumptions of the variance analysis. In these cases, significance tests were performed using the transformed data and the means were presented as the original data. Variance analysis using GLM SAS (2003) was applied to study each effect in the model adopting the farm as repetition, the group as experimental unit for the analysis of stomach weight and content data and the animal for the analysis of physiological and meat quality data. Farm was adopted as repetition. Variance analysis using GLM SAS (2003) was applied to study each effect in the model adopting the farm as repetition, the group as experimental unit for the analysis of stomach weight and content data and the animal as experimental unit for the analysis of physiological and meat quality data. The variance model analysis included effects of farm, season, on-farm fasting interval, lairage period, interaction between season, on-farm fasting interval and lairage period, and error supposedly homoscedastic, independent and normally distributed. A probability level of $P<0.05$ was chosen as the limit for statistical significance in all tests and probability levels of $P \leq 0.10$ were considered as a tendency. The detailing of the analysis, when necessary, was performed through the Tukey test used for multiple comparisons of means. In addition, when there was effect of on-farm fasting interval and lairage period at abattoir, the analysis was complemented with the response surface analysis for these two factors, evaluating the linear, quadratic and cross product effects.

\section{Results and discussion}

\section{Physiological stress indicators}

There were no interactions $(P>0.05)$ among studied effects (season vs. on-farm fasting interval vs. lairage period season). In contrast to other studies (Gispert et al. 2000; Baldwin and Stephens 1973; Dantzer and Mormede 1983), blood cortisol levels were not significantly influenced by fasting interval, lairage period or season $(P>0.05)$. However, there was a significant effect of season $(P<0.0001)$ on blood lactate level, which was greater in the summer (Table 2). Due to the greater energy demand, a higher blood cortisol can be observed under cold temperatures in order to maintain body temperature (Gispert et al. 2000; Baldwin and Stephens 1973; Dantzer and Mormede 1983). However, the absence of season effects in the present study may be explained by the low cortisol levels which evidently reflected good environmental and pre-slaughter handling conditions. Since pigs have limited abilities to heat loss, they are essentially susceptible to heat stress (Ingrain 1965; Adejumo and Egbunike 1988), which can explain the higher lactate concentrations found in pigs during summer (Dalla Costa et al. 2018). In the literature, the effects of fasting interval on cortisol levels are contradictory. While some authors (Houpt et al. 1983; Parrott and Misson 1989) observed an increase in blood and salivary cortisol levels starting from $15 \mathrm{~h}$ of fasting, Gispert et al. (2000) reported lower blood levels of cortisol in pigs fasted from 12 to $18 \mathrm{~h}$. However, the evidence of an increase in blood cortisol levels due to fasting was not confirmed in this study. Independently of fasting interval, an increase in blood cortisol levels can be associated with travel sickness, especially in pigs transported with full stomach, or by the greater demand for energy supply (von Mickwitz 1982). It was observed in the present study that pigs coped similarly with the challenge of pre-slaughter fasting intervals. Dalla Costa et al. (2016c) also failed to find variation in blood lactate concentration in pigs fasted on-farm and at abattoir, which was attributed to a confounding effect where this variable was increasing in one group and descending in the other one. In addition, the high values of $\mathrm{CV}$ found may reflect an individual effect on these variables and contributed to the lack of significant differences between treatments.

\section{Effects of on-farm fasting and lairage period on stomach weight and contents}

The behaviour of stomach content variables (feed; water; feed + water) was interpreted through the first principal component which found a positive association between feed + water content $(-0.880)$ and feed $(-0.923)$, and negative for water content $(0.998$; Fig. 1$)$. Treatments were

Table 2 Effects of season on blood stress indicators ${ }^{1}$

\begin{tabular}{llrl}
\hline Blood parameters & Winter & \multicolumn{1}{l}{ Summer } & $P$ value \\
\hline Cortisol $\left(\mathrm{mmol} \mathrm{L}^{-1}\right)$ & $7.95 \pm 0.20$ & $7.11 \pm 0.18$ & NS \\
Lactate $(\mu \mathrm{g} / \mathrm{dL})$ & $9.10 \pm 0.18$ & $12.28 \pm 0.10$ & $<0.0001$ \\
\hline
\end{tabular}

NS no significant difference was found

${ }^{1}$ Means and standard error 


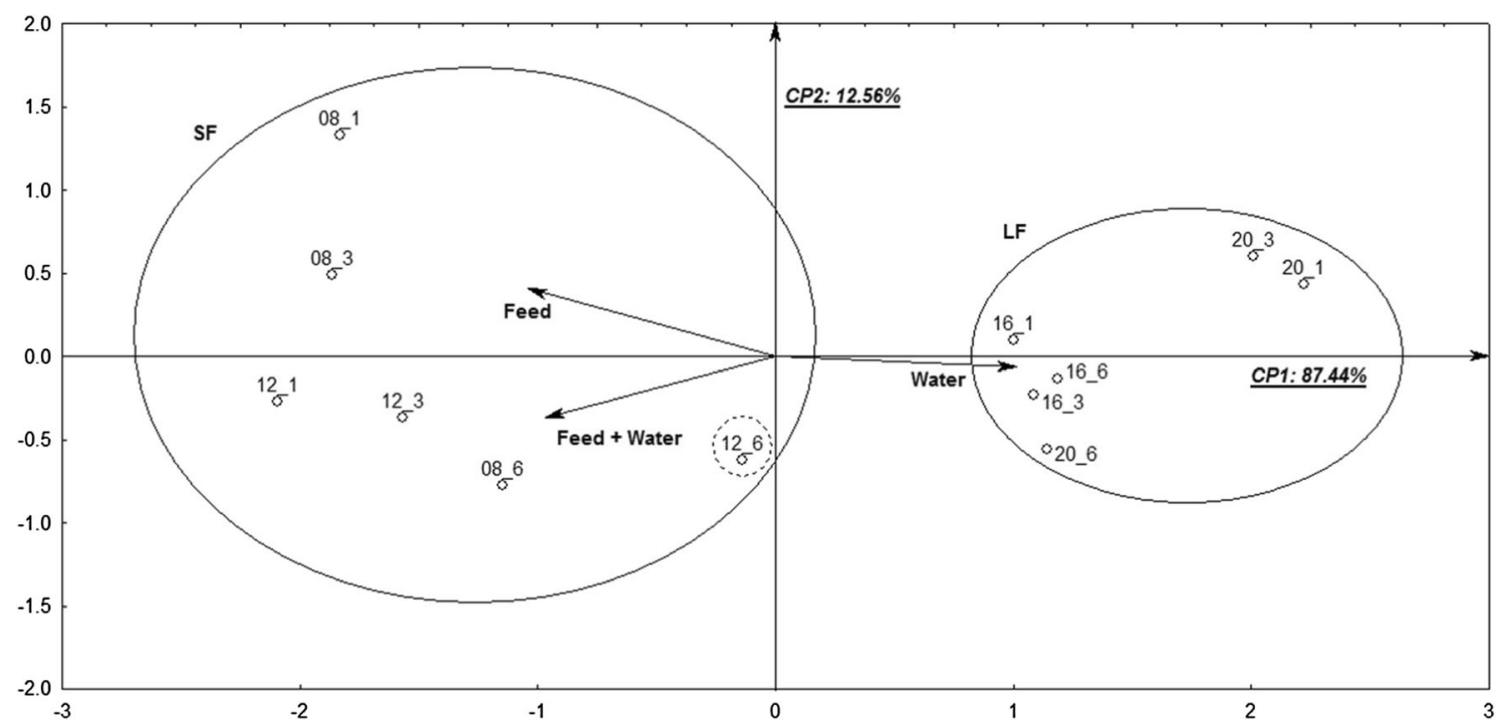

Fig. 1 Principal Components Analysis of stomach content weight of pigs according to on-farm fasting interval ${ }^{1}$ and lairage time ${ }^{2}$. SF shorter onfarm fasting interval, LF longer on-farm fasting interval. ${ }^{1,2}$ Numbers in

the figure separated by " " " means on-farm fasting interval and lairage period, respectively

lairage time $(P<0.0001)$, but the interaction between on-farm fasting interval and lairage time was significant $(P<0.01)$. There were no effects of any factor studied on classification of stomach weight. However, in the winter, pigs had heavier stomachs than in the summer $(407.94 \pm$ 13 versus $395.88 \pm 14.6, P<0.05)$. The results showed that weight of stomach contents reduces as the total feed withdrawal time increases (Table 3) up to on-farm fasting of 17 plus $1 \mathrm{~h}$ of lairage (Fig. 2). Based on this analysis, the use of an on-farm fasting interval of $16 \mathrm{~h}$ combined to $1 \mathrm{~h}$ of lairage period had similar results to the use of $12 \mathrm{~h}$ of on-farm fasting combined with $6 \mathrm{~h}$ of lairage to obtain empty stomach ( $\geq 350 \mathrm{~g}$; Chevillon 1994; Chevillon et al. 2006).

The literature reported a twofold greater stomach weight in pigs slaughtered non-fasted than fasted for 16 to $24 \mathrm{~h}$ (Kephart and Mills, 2005) and 6 than $24 \mathrm{~h}$ (Eikelenboom et al. 1991). Panella-Riera et al. (2012) found a lower frequency for empty stomachs at slaughter

Table 3 Effects of the interaction between on-farm fasting and lairage time ${ }^{1}$ on weight stomach content (g)

\begin{tabular}{|c|c|c|c|c|c|c|}
\hline \multirow[t]{2}{*}{ Lairage period (h) } & \multicolumn{5}{|c|}{ On-farm fasting interval (h) } & \multirow[t]{2}{*}{$P$ value } \\
\hline & 8 & 12 & 16 & 20 & Mean & \\
\hline 1 & $735.24 \pm 47.5^{\mathrm{a}}$ & $576.14 \pm 44.2^{\mathrm{ab}}$ & $271.17 \pm 18.7^{\mathrm{d}}$ & $256.35 \pm 20.1^{\mathrm{d}}$ & $461.60 \pm 21.1^{\mathrm{A}}$ & $<.0001$ \\
\hline 3 & $582.85 \pm 37.5^{\mathrm{ab}}$ & $511.49 \pm 36.1^{\mathrm{ab}}$ & $291.03 \pm 18.7^{\mathrm{cd}}$ & $298.93 \pm 24.5^{\mathrm{d}}$ & $419.94 \pm 16.7^{\mathrm{A}}$ & $<.0001$ \\
\hline 6 & $439.30 \pm 26.9^{\mathrm{cb}}$ & $337.53 \pm 23.6^{\mathrm{cd}}$ & $241.84 \pm 18.2^{\mathrm{d}}$ & $284.75 \pm 16.9^{\mathrm{d}}$ & $325.49 \pm 11.6^{\mathrm{B}}$ & $<.0001$ \\
\hline Mean & $585.82 \pm 23.4^{\mathrm{A}}$ & $474.62 \pm 21.5^{\mathrm{B}}$ & $267.88 \pm 10.7^{\mathrm{C}}$ & $280.21 \pm 12.0^{\mathrm{C}}$ & $401.91 \pm 9.90$ & $<.0001$ \\
\hline
\end{tabular}

\footnotetext{
${ }^{1}$ Means and standard error
}

${ }^{\mathrm{aA}, \mathrm{bB}}$ Different letters indicate statistically significant differences $(P<0.05)$ by Tukey test in the row (lowercase) and column (uppercase) considering the data log-transformed 


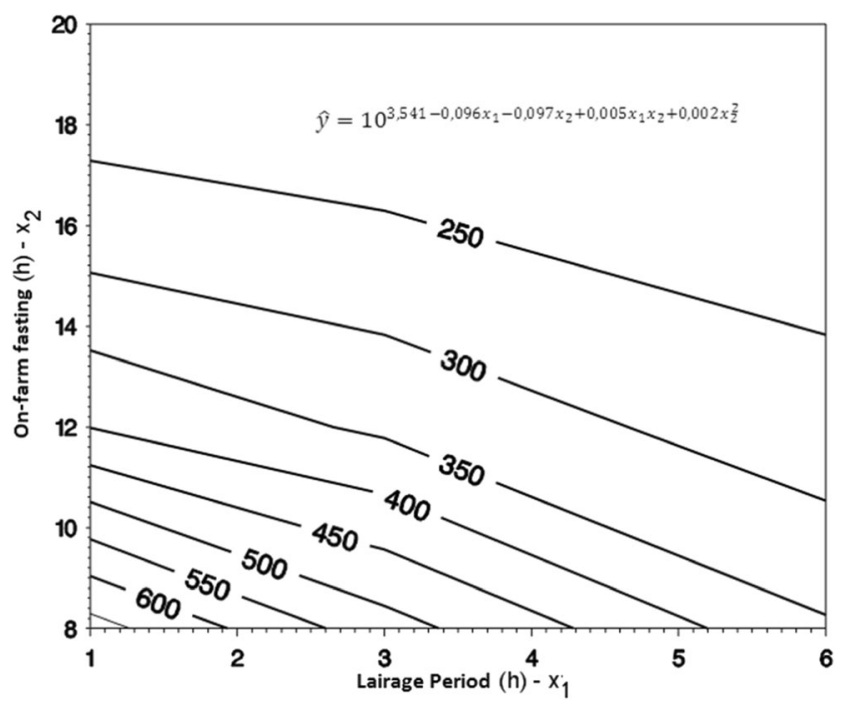

Fig. 2 Analysis of response surface of stomach weight according to on-farm fasting interval and lairage time $\left(\hat{y}=10^{3,541-0,096 x_{1}-0,097 x_{2}+0,005 x_{1} x_{2}+0,002 x_{2}^{2}}\right)$ $-R^{2}=88.4 \%$

in non-fasted pigs $(22.2 \%)$ than in pigs fasted for $12 \mathrm{~h}$ onfarm and slaughtered immediately $(77.8 \%)$ or pigs fasted for $12 \mathrm{~h}$ in the lairage (94.4\%). Miller et al. (1997) and Brown et al. (1999) reported that pigs subjected to a longterm $(24 \mathrm{~h})$ fast tend to increase the water intake. Rabaste et al., (2007) found that $23.5 \%$ of pigs had full stomachs at slaughter and mostly contained liquid (79.4\%) coming from water drunk in lairage after $22 \mathrm{~h}$ of fasting. In the event of stomach laceration in the dressing line, the liquids can spread more easily over the pig carcass and jeopardize meat safety compared with solid contents. Therefore, stomachs full of water at slaughter are a potentially greater risk for meat safety than solid contents. This finding confirmed that not only the stomach weight must be monitored at auditings for potential sources of carcass contamination at the abattoir, but also, the stomach content type. Indeed, the results also confirmed that pigs fasted for longer than $12 \mathrm{~h}$ on-farm or at abattoir might have higher stomach water content (Faucitano et al. 2010; Panella-Riera et al. 2012).

\section{Skin and carcass lesions}

Carcass lesions were significantly influenced $(P<0.0001)$ by season (Table 4). In contrast to previous reported (PanellaRiera et al. 2012), independently of the season, lairage period affected the incidence of carcass lesions unlike on-farm fasting interval (Table 5). Carcass lesions caused by fighting were greater $(P \leq 0.005)$ in the winter, mainly after 3 and $6 \mathrm{~h}$ of lairage $(P \leq 0.005)$.

The higher number of carcass lesions observed in the winter, which were mainly caused by fighting, may have been linked to the pigs huddling together to better cope with cold temperatures (Guise et al. 1996; Guàrdia et al. 2005). Huddling behaviour increases contact between pen mates leading to fighting or climbing over the backs of other pen mates to find a place to lie down and rest (Guise and Penny 1989; Lambooij and Engel 1991), and this is the likely reason for the difference found between seasons.

Some authors (Nanni Costa et al. 2002; Warriss 2003; Panella-Riera et al. 2012) suggested that pigs fasted for longer have a higher number of skin lesions. Dalla Costa et al. (2016a) reported that non-fasted pigs showed a higher number of fights and a longer total duration of fights during lairage than fasted $(18 \mathrm{~h})$ pigs. Indeed, non-fasted pigs continued fighting with the same intensity up to the third hour of lairage. However, differences in some factors such as mixing, facilities and practices used in each farm are likely to explain the lack of differences observed in this study. Especially in a new environment, when mixed with unfamiliar pigs, they start to explore the new pen and this increases the probability of interactions with new pen mates, resulting in higher incidence of fighting behaviour and, consequently, a higher skin lesion frequency. This may also explain why, in this study, pigs kept for longer at lairage showed higher carcass lesions at slaughter (i.e. pigs spent more time exploring the pen and/ or fighting with the new pen mates; Dalla Costa et al. 2016a). Nanni Costa et al. (2002) reported a higher incidence of the carcass lesions in pigs kept at lairage for $22 \mathrm{~h}$ compared to $12 \mathrm{~h}$.
Table 4 Effects of season on carcass lesion of pigs according to their causes ${ }^{1}$

\begin{tabular}{lllll}
\hline Type of lesion & \multicolumn{2}{l}{ Season } & Mean & $P$ value \\
\cline { 2 - 3 } & Winter & Summer & & \\
\hline Fight & $2.324 \pm 0.143$ & $0.626 \pm 0.069$ & $1.474 \pm 0.084$ & $<0.0001$ \\
Mounting & $1.615 \pm 0.063$ & $1.811 \pm 0.078$ & $1.713 \pm 0.050$ & NS \\
Handling & $5.114 \pm 0.166$ & $5.071 \pm 0.164$ & $5.093 \pm 0.117$ & NS \\
Total & $9.053 \pm 0.234$ & $7.508 \pm 0.199$ & $8.280 \pm 0.156$ & $<0.0001$ \\
\hline
\end{tabular}

NS no significant difference was found

${ }^{1}$ Means and standard error 
Table 5 Effects of lairage period and season on carcass lesion of pigs caused by fighting

\begin{tabular}{llllll}
\hline Season & \multicolumn{2}{l}{ Lairage period $(\mathrm{h})$} & & $P$ value \\
\cline { 2 - 5 } & 1 & 3 & 6 & Mean & \\
\hline Winter & $1.937 \pm 0.210 \mathrm{~b}$ & $2.620 \pm 0.294 \mathrm{a}$ & $2.418 \pm 0.231 \mathrm{ab}$ & $2.324 \pm 0.143$ & 0.004 \\
Summer & $0.635 \pm 0.119$ & $0.850 \pm 0.148$ & $0.389 \pm 0.079$ & $0.626 \pm 0.069$ & NS \\
Mean & $1.286 \pm 0.126 \mathrm{~b}$ & $1.730 \pm 0.171 \mathrm{a}$ & $1.406 \pm 0.135 \mathrm{ab}$ & $1.474 \pm 0.084$ & 0.012 \\
\hline
\end{tabular}

$N S$ no significant difference was found

${ }^{1}$ Means and standard error

\section{Meat quality}

There was a season effect (Table 6) and an interaction between season and lairage time on loin and ham $\mathrm{pH}_{\mathrm{u}}$, where $\mathrm{pH}_{\mathrm{u}}$ was lower $(P<0.05)$ for pigs slaughtered after $6 \mathrm{~h}$ of lairage during the summer (Table 7). In contrast to what is suggested in the literature (Panella-Riera et al. 2012; Eikelenboom et al. 1991; Warner et al. 1997; Warriss 1982), fasting interval did not raise $\mathrm{pH}_{\mathrm{u}}$ (Table 7). Independently of the on-farm fasting, lairage period and season, none of loins and hams had $\mathrm{pH}_{\mathrm{i}}<6.0$ or $\mathrm{pH}_{\mathrm{u}}>6$, which is indicative of PSE and DFD meat in pigs, respectively. However, mainly in the summer, animals kept at lairage for longer period $(6 \mathrm{~h})$ had a $\mathrm{pH}_{\mathrm{u}}$ value lower than 5.5 in loin and ham, which may indicate a mild pork quality defect. This study confirmed the negative effect of warm season on meat quality (Küchenmeister et al. 2000; Dalla Costa et al. 2007) especially with $6 \mathrm{~h}$ of lairage. During the warmer seasons, several abattoirs have applied shorter lairage periods in order to obtain higher quality of meat, however, without the support of literature.

Table 6 Effects of season on meat quality of pigs ${ }^{1}$

\begin{tabular}{lllll}
\hline Variable & \multicolumn{2}{l}{ Season effects } & \multirow{2}{*}{ P value } \\
\cline { 2 - 4 } & Winter & Summer & Mean & \\
\hline Loin & & & & \\
$\mathrm{pH}_{\mathrm{i}}$ & $6.278 \pm 0.012$ & $6.309 \pm 0.010$ & $6.293 \pm 0.008$ & $\mathrm{NS}$ \\
$\mathrm{pH}_{\mu}$ & $5.661 \pm 0.007$ & $5.530 \pm 0.005$ & $5.596 \pm 0.005$ & $<0.0001$ \\
$\mathrm{~L}^{*}$ & $44.99 \pm 0.13$ & $45.97 \pm 0.13$ & $45.48 \pm 0.09$ & $<0.0001$ \\
Drip loss & $2.698 \pm 0.079$ & $3.166 \pm 0.097$ & $2.934 \pm 0.063$ & 0.0027 \\
Ham & & & & \\
$\mathrm{pH}_{\mathrm{i}}$ & $6.327 \pm 0.012$ & $6.358 \pm 0.011$ & $6.343 \pm 0.008$ & $\mathrm{NS}$ \\
$\mathrm{pH}_{\mu}$ & $5.658 \pm 0.006$ & $5.529 \pm 0.006$ & $5.594 \pm 0.005$ & $<0.0001$ \\
$\mathrm{~L}^{*}$ & $45.10 \pm 0.12$ & $45.14 \pm 0.13$ & $45.12 \pm 0.09$ & $\mathrm{NS}$ \\
Drip loss & $2.261 \pm 0.066$ & $2.631 \pm 0.082$ & $2.447 \pm 0.053$ & 0.0074 \\
\hline
\end{tabular}

NS no significant difference was found

${ }^{1}$ Means and standard error. Only parameters with significant effect were shown
The variation in $\mathrm{pH}_{\mathrm{u}}$ values may suggest a state of fatigue in metabolic condition of pigs kept in lairage for longer. Dalla Costa et al. (2016a) reported increased and longer number of fights in non-fasted pigs kept longer at lairage, which can result in a rise in the depletion of muscle glycogen content and meat quality defects. During stressful conditions, adrenaline secretion results in increased glycogen breakdown in the muscle (Terlouw et al. 2008) and, consequently, lower $\mathrm{pH}_{\mathrm{u}}$ is found due to the production of lactate postmortem. Additionally, variations in $\mathrm{pH}_{\mathrm{u}}$ are mostly caused by postmortem metabolism and muscle glycogen content, which is influenced by factors such as psychological stress (Bourguet et al. 2011), season (Bourguet et al. 2011), transport (Dalla Costa et al. 2016c) and lairage (Bourguet et al. 2011; Chulayo et al. 2016; Dalla Costa et al. 2016a). Compared to pigs kept in lairage for 2 h, Nanni Costa et al. (2002) reported a darker, higher $\mathrm{pH}_{\mathrm{u}}$ and lower drip loss meat after overnight lairage. Some authors (Santos et al., 1997; Fraqueza et al., 1998; Dalla Costa et al. 2007) observed higher reflectance (paler muscles) during summer than winter.

\section{Conclusions}

Commercial practices such as an on-farm fasting interval and lairage period at the abattoir may significantly affect animal welfare, carcass and meat quality traits. Indeed, these interactions between season and preslaughter practices should be considered whenever the effects of pre-slaughter handling on animal welfare, carcass and meat quality traits are significant. The application of $12 \mathrm{~h}$ of on-farm fasting with $6 \mathrm{~h}$ of lairage seemed to be best combination to reduce stomach content weight (feed and water). Mainly in the winter, shorter lairage period can be used to reduce percentage of skin lesions and better pork quality traits in pigs. However, to obtain all these advantages, it is fundamental that producers and abattoirs have a good communication channel to plan the logistics of this phase of preslaughter handling which can be done by technicians in cooperative systems or also by producers when planning the shipping of animals. 
Table 7 Effects of the interaction between season and lairage period on meat quality of pigs ${ }^{1}$

\begin{tabular}{|c|c|c|c|c|c|}
\hline \multirow[t]{2}{*}{ Variable } & \multirow[t]{2}{*}{ Season } & \multicolumn{3}{|l|}{ Lairage (h) } & \multirow[t]{2}{*}{$P$ value } \\
\hline & & 1 & 3 & 6 & \\
\hline \multicolumn{6}{|l|}{ Loin } \\
\hline \multirow[t]{3}{*}{$\mathrm{pH}_{\mu}$} & Winter & $5.63 \pm 0.01$ & $5.68 \pm 0.01$ & $5.67 \pm 0.01$ & 0.0703 \\
\hline & Summer & $5.58 \pm 0.01^{\mathrm{a}}$ & $5.53 \pm 0.01^{\mathrm{ab}}$ & $5.49 \pm 0.01^{\mathrm{b}}$ & 0.0004 \\
\hline & Mean & $5.60 \pm 0.00$ & $5.61 \pm 0.01$ & $5.58 \pm 0.01$ & NS \\
\hline \multicolumn{6}{|l|}{ Ham } \\
\hline \multirow[t]{3}{*}{$\mathrm{pH}_{\mu}$} & Winter & $5.64 \pm 0.01$ & $5.67 \pm 0.011$ & $5.66 \pm 0.01$ & NS \\
\hline & Summer & $5.60 \pm 0.010^{\mathrm{a}}$ & $5.50 \pm 0.007^{\mathrm{b}}$ & $5.49 \pm 0.01^{\mathrm{b}}$ & $<0.0001$ \\
\hline & Mean & $5.62 \pm 0.01^{\mathrm{a}}$ & $5.59 \pm 0.01^{\mathrm{ab}}$ & $5.57 \pm 0.01^{\mathrm{b}}$ & 0.0051 \\
\hline
\end{tabular}

NS no significant difference was found

${ }^{1}$ Means and standard error. Only parameters with significant effect were shown

\begin{abstract}
Acknowledgments The authors appreciate the assistance of Antonio Lourenço Guidoni (in memorian) for the incentive and help in the experimental design. Sincere thanks to CNPQ (National Council of Technological and Scientific Development) for granting a PhD scholarship to Filipe Dalla Costa, to EMBRAPA Swine and Poultry for financial support and to Coperdia and Aurora for the facilities usage. We appreciated the help of Neville George Gregory for the critical review of the manuscript.
\end{abstract}

\section{Compliance with ethical standards}

The animal handling procedures used in this research were approved by the São Paulo State University's Animal Research Ethics Board (protocol number 6119-08).

Conflicts of interest The authors declare that they have no conflict of interest.

\section{References}

Aaslying MD, Barton Gade P (2001) Low stress pre-slaughter handling: effect of lairage time on the meat quality of pork. Meat Sci 57:87-92

ABIPECS - Brazilian Pork Industry and Exporter Association. Associação brasileira de proteína animal (2016) http:// www. abipecs.org.br/pt/estatisticas/mundial/producao-2.html. Accessed 07 March 2017

Adejumo DO, Egbunike GN (1988) Effect of thermal stress and water deprivation on the acetylcholinesterase activity of the pig brain and hypophyses. Int J Biometeorol 32:108-111

Averós X, Knowles TG, Brown SN, Warriss PD, Gonsálvez LF (2008) Factors affecting the mortality of pigs being transported to slaughter. Vet Rec 163:386-390

Baldwin BA, Stephens DB (1973) The effects of conditioned behaviour and environmental factors on plasma corticosteroid levels in pigs. Physiol Behav 10:267-274

Bourguet C, Véronique D, Tannugi CC, Terlouw EMC (2011) Behavioural and physiological reactions of cattle in a commercial abattoir: relationships with organisational aspects of the abattoir and animal characteristics. Meat Sci 88:58-168

Bradshaw RH, Parrott RF, Goode JA, Lloyd DM, Rodway RG, Broom DM (1996) Behavioural and hormonal responses of pigs during transport: effect of mixing and duration of journey. Anim Sci 62: $547-554$
Brown SN, Knowles TG, Edwards JE, Warriss PD (1999) Relationship between food deprivation before transport and aggression in pigs held in lairage before slaughter. Vet Rec 145:630-634

Chevillon P (1994) Le contrôle des estomacs de porcs à l'abattoir : miroir de la mise à jeun en élevage. Techni-Porc 17:23-30

Chevillon P, Vautier A, Gault E (2006) Quand sortir les porcs charcutiers sur le local d'embarquement à l'élevage ? Impact sur le rendement carcasse, le poids des estomacs, la qualité de la viande et les rendements à la transformation en jambons cuits. Techni-Porc 29: $1-7$

Chulayo AY, Bradley G, Muchenje V (2016) Effects of transport distance, lairage time and stunning efficiency on cortisol, glucose, HSPA1A and how they relate with meat quality in cattle. Meat Sci 117:89-96

Correa JA, Méthot S, Faucitano L (2007) A modified meat juice container (EZ-DripLoss) procedure for a more reliable assessment of drip loss and related quality changes in pork meat. J Muscle Foods 18:67-77

Dalla Costa OA, Faucitano L, Coldebella A, Ludke JV, Peloso JV, Dalla Roza D, Paranhos da Costa MJR (2007) Effects of the season of the year, truck type and location on truck on skin lesions and meat quality in pigs. Livest Prod Sci 107:29-36

Dalla Costa FA, Devillers N, Paranhos da Costa MJR, Faucitano L (2016a) Effects of applying preslaughter feed withdrawal at the abattoir on behaviour, blood parameters and meat quality in pigs. Meat Sci 119:89-94

Dalla Costa FA, Paranhos da Costa MJR, Faucitano L, Dalla Costa OA, Lopes LS, Renuncio E (2016b) Ease of handling, physiological response, skin lesions and meat quality in pigs transported in two truck types. Arch Med Vet 48:299-304

Dalla Costa FA, Lopes LS, Dalla Costa OA (2017) Effects of the truck suspension system on animal welfare, carcass and meat quality traits in pigs. Anim 7:5-18

Dalla Costa OA, Feddern V, Athayde NB, Manzke NE, Roça RDO, Lopes LDS, Lima GJMMD (2018) Ractopamine supplementation improves leanness and carcass yield, minimally affecting pork quality in immunocastrated pigs. Sci Agric 75:197-207

Dantzer R, Mormede P (1983) Stress in farm animals: a need for reevaluation. J Anim Sci 1:6-18

Eikelenboom G, Hoving-Bolink AH, Sybesma W (1991) Effects of feed withdrawal before delivery on pork quality and carcass yield. Meat Sci 29:25-30

Faucitano L, Chevillon P, Ellis M (2010) Effects of feed withdrawal prior to slaughter and nutrition on stomach weight, and carcass and meat quality in pigs. Livest Sci 127:110-114

Fraqueza MJ, Roseiro LC, Almeida J, Matias E, Santos C, Randall JM (1998) Effects of lairage temperature and holding time on pig behaviour and carcass and meat quality. Meat Sci 60:317-330 
Gispert M, Faucitano L, Guàrdia MD, Oliver MA, Colla C, Siggens K, Harveyb K, Diestre A (2000) A survey on pre-slaughter conditions, halothane gene frequency, and carcass and meat quality in five Spanish pig commercial abattoirs. Meat Sci 55:97-106

Guàrdia MD, Estany $\mathrm{J}$, Balasch $\mathrm{S}$, Oliver MA, Gispert M, Diestre A (2004) A risk assessment of PSE condition due to pre-slaughter conditions and RYR1 gene in pigs. Meat Sci 67:471-478

Guàrdia MD, Estany J, Balasch S, Oliver MA, Gispert M, Diestre A (2005) A risk assessment of DFD meat due to preslaughter conditions in pigs. Meat Sci 70:709-716

Guàrdia MD, Estany J, Balasch S, Oliver MA, Gispert M, Diestre A (2009) Risk assessment of skin damage due to pre-slaughter conditions and RYR1 gene in pigs. Meat Sci 81:745-751

Guise HJ, Penny RHC (1989) Factors influencing the welfare and carcass and meat quality of pigs: 1 . The effects of stocking density in transport and the use of electric goads. Anim Prod 49:511-515

Guise HJ, Hunter EJ, Baynes PJ, Wigglesworth PJ, Riches HL, Penny RHC (1996) Observation of the behaviour of slaughter pigs during transport. Pig J 38:19-29

Houpt KA, Baldwin BA, Houpt TR, Hills F (1983) Humoral and cardiovascular responses to feeding in pigs. J Physiol 244:279-284

Ingrain DL (1965) Evaporative cooling in the pig. Nature 207:415-416

Kephart KB, Mills EW (2005) Effect of withholding feed from swine before slaughter on carcass and viscera weights and meat quality. $\mathrm{J}$ Anim Sci 83:715-721

Küchenmeister U, Kuhn G, Ender K (2000) Seasonal effects on $\mathrm{Ca}^{2+}$ transport of sarcoplasmic reticulum and on meat quality of pigs with different malignant hyperthermia status. Meat Sci 55:239-245

Lambooij E, Engel B (1991) Transport of slaughter pigs by road over a long distance: some aspects of loading density and ventilation. Livest Prod Sci 28:163-174

Leheska JM, Wulf DM, Maddock RJ (2002) Effects of fasting and transportation on pork quality development and extent of postmortem metabolism. J Anim Sci 80:3194-3202

Miller MF, Carr MA, Bawcom DB, Ramsey CB, Thompson LD (1997) Microbiology of pork carcasses from pigs with differing origins and feed withdrawal times. J Food Prot 60:242-245

Nanni Costa L, Lo Fiego DP, Dall'Olio S, Davoli R, Russo V (2002) Combined effects of pre-slaughter treatments and lairage time on carcass and meat quality in pigs of different halothane genotype. Meat Sci 61:41-47

NFANC - National Farm Animal Care Council (2014) Codes of practice for the care and handling of pigs https://www.nfacc.ca/codes-ofpractice/pigs. Accessed 25 January 252016

O'Neill DDJ, Lynch PB, Troy DJ, Buckley DJ, Kerry JP (2003) Influence of the time of year on the incidence of PSE and DFD in Irish pig meat. Meat Sci 64:105-111
Panella-Riera N, Gispert M, Gil M, Soler J, Tibau J, Oliver MA, Velarde A, Fàbrega E (2012) Effect of feed deprivation and lairage time on carcass and meat quality traits on pigs under minimal stressful conditions. Livest Sci 146:29-37

Parrott RF, Misson BH (1989) Changes in pig salivary cortisol in response to transport simulation, food and water deprivation, and mixing. Br Vet J 145:501-505

Pinheiro Machado Filho, LC (2000) Pig welfare and meat quality: a Brazilian view. In: $1^{\text {st }}$ International Virtual Conference on Pork Quality - Welfare, Transport and Consumer. Embrapa Publ., Concordia, Brazil, pp 32-38

Rabaste C, Faucitano L, Saucier L, Foury D, Mormède P, Correa JÁ, Giguère A, Bergeron R (2007) The effects of handling and group size on welfare of pigs in lairage and its influence on stomach weight, carcass microbial contamination and meat quality variation. Can J Anim Sci 87:3-12

Santos C, Almeida JM, Matias EC, Franqueza MJ, Roseiro C, Sardinha L (1997) Influence of lairage environmental conditions and resting time on meat quality in pigs. Meat Sc 45:253-262

Saucier L, Bernier D, Bergeron R, Giguere A, Methot S, Faucitano L (2007) Effect of feed texture, meal frequency and pre-slaughter fasting on behaviour, stomach content and carcass microbial quality in pigs. Can J Anim Sci 87:479-487

Schwartzkopf-Genswein KSG, Faucitano L, Dadgar S, Shand P, González LA, Crowe TG (2012) Road transport of cattle, swine and poultry in North America and its impact on animal welfare, carcass and meat quality: a review. Meat Sci 92:227-243

Terlouw C, Arnould C, Auperin B, Berri C, Bihan-Duval E, Deiss V, Lefèvre F, Lensink BJ, Mounier L (2008) Pre-slaughter conditions, animal stress and welfare: current status and possible future research. Anim 2:1501-1517

von Mickwitz G (1982) Various transport conditions and their influence on physiological reactions. In: Moss R (ed) Transport of animals intended for breeding, production and slaughter, vol 1. Martinus Nijho Publishers, The Hague, pp 45-54

Warner RD, Kauffman RG, Greaser ML (1997) Muscle protein changes postmortem in relation to pork quality traits. Meat Sci 45:339-352

Warriss PD (1982) Loss in carcass weight, liver weight and liver glycogen and the effects on muscle glycogen and ultimate $\mathrm{pH}$ in pigs fasted preslaughter. J Sci Food Agric 33:840-846

Warriss PD (2003) Optimal lairage times and conditions for slaughter pigs: a review. Vet Rec 153:170-176

Young JF, Bertram HC, Oksbjerg N (2009) Rest before slaughter ameliorates pre-slaughter stress-induced increased drip loss but not stressinduced increase in the toughness of pork. Meat Sci 83:634-641 